\title{
Kişisel Satışta Sosyal Sermayenin Müşteri İlişkilerine Etkisi Üzerine Bir Araştırma (The Effects of Social Capital on Customer Relations in Personal (Direct) Sales)
}

\section{Zafer EROL iD a Yasin BOYLU iD $b$}

a Ankara Hacı Bayram Veli Üniversitesi, Lisansüstü Eğitim Enstitüsü, İşletme Bölümü, Ankara, Türkiye. zafer erol@hotmail.com.tr b Ankara Hacı Bayram Veli Üniversitesi, Turizm Fakültesi, Turizm İşletmeciliği Bölümü, Ankara, Türkiye. yasin.boylu@hbv.edu.tr

\begin{tabular}{|c|c|}
\hline MAKALE BİLGİSİ & ÖZET \\
\hline Anahtar Kelimeler: & $\begin{array}{l}\text { Amaç - Bu çalışmada kişisel satış alanında sosyal sermayenin müşteri ilişkileri üzerinde olumlu ve } \\
\text { olumsuz etkilerinin tespit edilmesi ve sosyal sermayenin kişisel satış yoluyla pazarlama faaliyeti } \\
\text { yürüten işletmeler için ne düzeyde etkili olabildiğinin tespit edilmesi amaçlanmıştır. }\end{array}$ \\
\hline $\begin{array}{l}\text { Sosyal Sermaye } \\
\text { Müşteri İliş̧kileri }\end{array}$ & $\begin{array}{l}\text { Yöntem - Kişisel satışta sosyal sermayenin müşteri iliş̧kilerine etkileri üzerine olan bu çalışmada, } \\
\text { çalışanın sahip olduğu birçok özelliğin yanında sosyal sermayesinin işletmenin başarısında ve } \\
\text { dolayısı ile kişinin başarısında önemli düzeyde etkili olduğuna yönelik tespitler yapılmış̧ır. Bu } \\
\text { araştırmanın amacı doğrultusunda Türkiye'de madeni yağ sektöründe faaliyet gösteren firmalarda } \\
\text { çalışan satış yetkilileri ile mülakat yapılmıştır. }\end{array}$ \\
\hline $\begin{array}{l}\text { Gonderılme Tarıhı } \\
\text { Revizyon Tarihi } \\
\text { Kabul Tarihi }\end{array}$ & $\begin{array}{l}\text { Bulgular - Mülakatlarda araştırmacıların sahip oldukları sosyal sermayelerinin satış faaliyeti } \\
\text { sırasındaki müşteri ilişkilerine önemli etkileri olduğu tespit edilmiştir. Elde edilen bulgular, satış } \\
\text { yetkililerinin sosyal sermayelerinin hem müşteri ilişkileri üzerinde pozitif etkileri olduğuna hem } \\
\text { de sosyal sermaye düzeylerine göre müşteri davranışlarının farklılaştığına işaret etmektedir. } \\
\text { Sosyal sermaye düzeyi yükseldikçe hem ticari hem de sosyal faydanın arttığ1 görülmektedir. }\end{array}$ \\
\hline $\begin{array}{l}\text { Makale Kategorisi: } \\
\text { Araştırma Makalesi }\end{array}$ & $\begin{array}{l}\text { Tartışma - Araştırmanın çıktıları, katılımcıların sahip oldukları sosyal sermayelerini müşteriler ile } \\
\text { ilk temas kurulması noktasında kullandıklarının tespiti, sosyal sermaye düzeylerinin rekabette } \\
\text { fark yarattığı ve sosyal sermaye düzeyi yüksek olan satış yetkililerinin daha başarılı olduğuna } \\
\text { işaret etmektedir. }\end{array}$ \\
\hline
\end{tabular}

\begin{tabular}{l}
\hline ARTICLE INFO \\
\hline Keywords: \\
Personel (Direct) Sales \\
Social Capital \\
Customer Relations
\end{tabular}

\section{ABSTRACT}

Purpose - In this study, it is aimed to determine the positive and negative effects of social capital on customer relations in the field of personal sales and to determine the extent to which social capital can be effective for the companies that carry out marketing activities through personal sales and to provide a reference resource for the enterprises.

Customer Relations

Design/methodology/approach - In this study on the effects of social capital on customer relations in personal sales, it has been determined that social capital has a significant effect on the success of the company and therefore on the success of the person, along with many other features of the

Received employee. For the purpose of this research the interviews are conducted with sales representatives

Revised working in companies operating in the mineral oil industry in Turkey.

Accepted

Findings - During the interviews, it was determined that the social capital of the researchers had significant effects on the customer relations during the sales activity. As a result of the findings, it is seen that the social capital of the sales authorities has an effect on the customer relations and the customer behaviors differ according to the social capital levels. As the level of social capital increased, both commercial and social benefits increased.

Article Classification:

Research Article

Discussion - The most important outputs of the research are that the participants use their social capital in the first contact with customers, that the social capital levels make a difference in competition and the sales authorities with high social capital level are more successful. 


\section{Giriş}

Teknolojik değişim ve bununla birlikte sürekli değişim gösteren müşteri istek ve ihtiyaçları işletmeleri yoğun bir rekabetin içine çekerek varlıklarını sürdürebilmeleri için farklı stratejiler geliştirmelerine sebep olmaktadır. Bu noktada işletmeler ürünlerini müşterilere ulaştırırken birçok farklı pazarlama yöntemleri kullanmaktadırlar. Ürüne, pazara ve şirket kültürüne de bağlı olarak tercih edilen bu pazarlama yöntemleri arasında en etkili yöntem olarak kişisel satış ön planda gelmektedir. Pazarlamanın tutundurma faaliyetlerinden olan kişisel satış pahalı bir yöntem olmasına rağmen sürekli artan rekabet nedeni ile giderek önem kazanmaktadır (Assael, 1990:500). İşletmelerin yüksek rekabet şartlarında karlılıklarını ve pazardaki paylarını artırmak suretiyle rakiplerinin önüne geçebilmesinde kişisel satışı gerçekleştirecek olan satış temsilcileri çok önemli bir yere sahiptir. Bu sebeple işletmeler, en önemli gücü olan kişisel satış yapan personelleri seçerken firmayı temsil edebilecek eğitim düzeyine sahip, prezentabl, kendine güvenen, girişken ve nihayetinde sosyal sermaye düzeyi yüksek olmasına dikkat etmektedirler (Tuncer, 2008: 127).

Kişisel satış müşteri ilişkilerinde en eski iletişim yöntemlerinden biri olup tanıtımda oldukça etkili bir yaklaşımdır (Uslu, 2006: 5-10). Kişisel satış ile sağlanan karşılıklı etkileşimle taraflar birbirlerini daha iyi tanıma, daha doğru hedef belirleme ve anlık geri bildirim nedeni ile sonuç odaklı aksiyon alabilme imkânına sahip olduğundan dolayı bu yöntem tercih edilmektedir (Tuncer, 2008: 46). Önceleri satın alma yetkilileri ihtiyacı olan ürünleri temin etmek için tedarikçileri ziyaret edip en uygun ürünü seçerken, şimdilerde tedarikçiler satış personelleri ile ürettikleri ürünü satabilmek için firmaları tek tek ziyaret ederek satış yapmaya çalışmaktadırlar. Bu satış esnasında ürün ve işletme hakkında bilgi verilerek müşterinin elde edeceği avantajlar sıralanmak suretiyle satın alma yetkilisi ikna edilmeye çalışılmaktadır. B2B (Business to Business - İşletmeden İşletmeye) ve/ya B2C (Business to Customer - İşletmeden Müşteriye) satış diye de isimlendirilen bu süreçte çok titiz bir çalışma yürütülmektedir. Bu sürecin en önemli faktörü ve aynı zamanda işletmenin yüzü olarak nitelendirilen satış yetkilisinin yeteneği, bilgisi, deneyimi ve sosyal çevresi sonucu doğrudan etkilemektedir (Kotler ve Armstrong, 2008:466; ).

İşletmeler ürün ve/ya hizmetlerini satabilmek için ürün bazlı stratejilerden değer bazlı stratejilere geçiş yapmaktadırlar. Ürünün kendisinin dışında müşteriler ile kurulan ilişki önem kazanmıştır. Müşterinin gelişen iletişim teknolojisinin etkisiyle istediği ürünü zaman ve mekâna bağlı kalmaksızın satın alabilir hale gelmesi kitlesel pazarlamanın önemini yitirmesiyle sonuçlanmıştır. Bu noktada müşteri ile kurulan birebir ilişki önem kazanmıştır. Satış yetkilisinin müşterisine sunacağı değer müşterinin karar vermesinde etkili olmaktadır (Parıltı, 2003:5-6; Çabuk, 1999: 3). Bilgi çağıyla birlikte gelen uzmanlaşma, teknolojik gelişmeler, ekonomik ve sosyal değişimler ile birlikte finansal sermayenin tek başına ekonomik ve sosyal hayat için belirleyici bir unsur olmadığı ortaya çıkmıştır (Baker, 2000: 1). Bu noktada sermaye parasal ve maddi anlamda değerini kaybetmeye başlamıştır. Eğitimin ve beşeri yeteneğin bir sermaye şekli olarak ortaya çıkması sermaye kavramında tanımın ve içeriğin değişmesine neden olmuştur. Bu değişimle birlikte sermaye kavramında eğitim ve bilgi biriminin yanında sosyal ilişkilerin ve güvenin sosyal süreçler için vazgeçilmez olduğu bir sermaye şekli olan sosyal sermaye öne çıkmıştır (Tüylüoğlu, 2006: 15).

Genel olarak sosyal sermaye, sinerji oluşturan bir unsur olarak da tanımlanabilir. Sosyal sermaye, kişilerin tek başlarına başarabileceklerinden çok daha fazla hareket edebilme imkânı yaratan sosyal ilişkiler şeklinde tanımlanmaktadır. Bu kavram ile insanlar arasındaki ilişki faktörü ortaya çıkarken, bu ilişkinin sosyoekonomik etkisi ön plana çımaktadır. Toplumların ilişkilerine bağlı olan ekonomik gelişimleri ortaya çıkartmayı amaçlayan bir ekonomik olgu şeklinde belirtilmektedir. Dar çerçevede, iki kişi arasındaki güven merkezli oluşan iletişim şeklinde açıklanır. Geniş çerçevedeyse, sosyal yapıları meydana getiren kişilerin, sivil toplum kuruluşlarının ve kamu kurumlarının aralarındaki koordinasyonu sağlayarak, verimi yükselten, güven sağlayan iletişim ağı şeklinde tanımlanmaktadır (Karagül ve Masca, 2005: 39).

Küreselleşen dünyada özgün ve yenilikçi fikirlerin geliştirilmesi, pazarlama süreçlerinde fark yaratırken; bu noktada tüketicileri etkileyen hikâyelerin anlatılması ürün ve fikirlerin zihinlerde yer edinmesi açısından önemlidir. Bunun için de çok sayıda kişiyle temas kurmak gerekmektedir (Kotler, 2010: 66-67). Doğrudan satış yani bir diğer ifadeyle kişisel satış yüksek kaliteli ve özel ürünlerin kişisel ilişkiler kurularak müşterilere ulaştırılmasının bir yoludur. Satın alınmak istenen ürünlerin tanınan, bilinen ve güvenilen kurum, kuruluş ve kişilerden devamlı olarak temin edilmesidir. Kişisel satışın bir diğer özelliği de, bağımsız satıcıların ürünlerin ve hizmetlerin temin edilmesinde üstlendikleri rollerdir. 
Kişisel satış sistemi benzer şekilde diğer farklı satış kanallarındaki gibi tüketiciler için ürün ve hizmet sunmaktadır. Bu yöntemin ana farklılığı müşteri ile satıcı arasında çok farklı bir kanal/yöntem kullanarak ortak noktada buluşturabilmesidir. Satış temsilcisi çalıştı̆̆ firmayı temsil etmektedir. Bu sebeple müşteriler satış temsilcinin tüm hareket ve davranışlarını gözlemlemektedirler. Firma ve ürünle ilgili müşteriye aktarılan bilgilerle müşteride marka imajı oluşacaktır (İslamoğlu ve Altunışık, 2009: 36). Kişisel satış yöntemi kullanan işletmeler diğer birçok faktörün yanında satıcıların satış gücüyle ve sosyal çevreleriyle iş yapar. Müşteri ile kişisel ilişki geliştirilir, satışın başarısı bağımsız satıcı ile müşteri arasındaki ilişkiye bağlıdır. Satış sadece sabit mağazada müşteri ile doğrudan ilişki kurarak veya internet ortamında olduğu gibi yapılmamaktadır; satış, farklı birçok ev, iş, sosyal ortamda gerçekleşebilmektedir. Her satış elemanının seçimi ve çeşitli aşamalardan sonra işe yerleştirilmesi hem zaman alan hem de maliyeti yüksek bir süreçtir (Spiro ve Stanton,2003:125).

Bağımsız satıcı diğer satıcılardan çok farklı bir fonksiyon üstlenir, bağımsız satıcı pazarlama planı yaparken, promosyon aktivitelerini organize edip, bütçeyi yönetimini, takım yönetimini gerçekleştirerek gerçek bir işletme sahibi gibi hareket eder. Bu durum, kişisel satıcının kabiliyetlerini, potansiyellerini ortaya çıarmaktadır. Bu potansiyellerden bir tanesi de kişisin sahip olduğu sosyal sermayesidir. Sosyal sermaye kaynaklarının toplamı, karşılıklı tanışma ve tanıma, daha fazla kurumsallaşmış ilişkiler ağına sahip gerçek ya da sanal bir grubu ifade etmektedir (Sabatini, 2006: 4). Buradan yola çıkarak beşeri sermayenin verimliliğini etkileyen en önemli faktörün sosyal sermaye olduğu söylenebilir (Kar ve Taban, 2014: 143).

$\mathrm{Bu}$ çalı̧̧mada kişisel satış, sosyal sermaye ve müşteri ilişkileri kavramlarından hareketle; kişisel satışta sosyal sermayenin müşteri ilişkileri üzerinde etkilerini tespit etmek amacıyla yapılan bir araştırmaya yer verilmiştir.

\section{Kavramsal Çerçeve}

\subsection{Kişisel Satış}

Eski Yunan tarihinde değiş - tokuş faaliyeti olarak adlandırılan satış ile birlikte satışçı kavramının da bu tarihte görüldüğü literatürde yer almaktadır (Gürcü, 2007: 42). Daha sonraları özellikle ilk çağda ve orta çağda pek de pozitif bir imajı olmayan satıcı kavramı o çağlarda satışa önem verilmemesi ve satışçılara güvenilmemesi nedeniyle aldatıcllık ile eş tutulmuştur (Tuncer, 2008: 3). Sanayi devrimi sonrasında ise tacirler yerini satış temsilcilerine bırakmıştır. Demir yolları ve telgraf satışı hızlandırarak satış temsilcilerinin merkezleri ile daha hızlı ve rahat iletişim kurmalarına imkân sağlamıştır. Ayrıca ürünlerin müşterilere ulaşımında hız kazanılmıştır. Bu dönemde satış temsilciliği tarıma bağlı ekonomiden seri üretimin ve etkin taşımacıllğın olduğu ekonomiye geçişte önemli rol oynamıştır (Uslu, 2006: 5-10). Ürün çeşitliliğindeki artış, maliyetlerin öneminin artması, sürekli değişen tüketici istek ve ihtiyaçlarının önceden bilinememesiyle birlikte kişisel satış daha da önem kazanmaya başlamıştır (Kirman, 1998:19-20).

Satışın temeli, ihtiyaçların doğru olarak tespiti, sonrasında bu ihtiyaçların karşılanmasını sağlayacak çözümler ile müşterilerin sağlayacağı faydanın doğru bir şekilde sunulmasıdır. Satışı klasik olarak; mal ve/ya hizmetin bir değer karşılığında el değiştirmesi olarak tanımlamak mümkündür. Kısa bir süre öncesine kadar satıcı, alıcı ve müşteriler arasında bir mücadele gibi görünen satış, artık hem satıcının hem de alıcının ortak çıkar elde ettikleri bir unsur olarak görülmeye başlamıştır. Bu noktada satış temsilcisi müşterinin istek ve ihtiyaçlarını doğru belirleyerek ve müşteriyi memnun edecek çözümler üreterek çözüm odaklı yaklaşmaktadır. Kişisel satış ve faaliyetlerinin yönetimi tutundurma karmasının temel alanlarındandır. Kişisel satışta müşterilerin belirlenmesi, bulunması, satın almalarına yardım edilmesi, satışın yapılması ve satış sonrasında müşteri ilişkilerinin oluşturulmasını amaçlayan bir doğrudan iletişim şeklidir (Eser ve diğerleri, 2011:564-565).

Kısaca kişisel satışı "Bir mal veya hizmet için satın alıcının ihtiyacını araştırarak, bu ihtiyacı en iyi karşılayan ürünü veya hizmeti tavsiye etmektir" (Taşkın, 2010: 74) şeklinde tanımlamak mümkündür. Kişisel satış, satış temsilcisinin mevcut ve/ya hedeflenen potansiyel müşterilerle doğrudan ve sözlü biçimde satış hareketine geçme yöntemi olarak da tanımlanabilir (Çelik ve Şimşek, 2012:252). İşletmeler, ürettikleri/sundukları mal ve/ya hizmet hakkında bilgi verilmesi, ürünlere olan ilginin artırılması, tüketici için ürün seçeneğinin geliştirilmesi, satış koşullarının görüşülmesi, satışın gerçekleştirilmesi gibi birçok gayeyle kişisel satış faaliyetleri yürütmektedir. Benzersiz ve yenilikçi bir fikirlerin geliştirilmesi, pazarlama süreçlerinde fark 
yaratmaktadır. Müşterileri etkileyen hikâyelerin anlatılması, ürünün zihinlerde yer etmesinde önemli rol oynamakta ve bu nedenle çok sayıda insanla temas kurulması gerekmektedir (Kotler, 2010: 66-67).

\subsection{Sosyal Sermaye}

İktisat bilimi ile anılan ve onun üretmiş olduğu bir kavram olarak tanımlanan sermaye, son zamanlarda sosyolojide de kendisine yer bulmakta ve popülaritesi artmaktadır. Sosyal sermaye kavramı ile ilgili yaklaşımları iktisat ve sosyoloji kavramlarının kesişmesiyle ortaya çıtı̆̆ı ve kişilerin aralarında kurduğu ilişkilerin bir kaynak özelliğine sahip olması nedeniyle toplumu oluşturan bireylere muhtelif avantaj ve faydalar sağlayabileceği gerekçesiyle hareket ettiği söylenebilir (Çakar, 2008:8). Sosyal sermaye denilince temel olarak sosyal iletişimi sağlayan ağlarının çok kıymetli bir değer olduğu yargısı ön plana çıkmaktadır. Toplum/örgüt/grup üyelerinde iletişim bağlarının varlığı sosyal bağlılığın/bağlantının temelini oluşturur. Sosyal bağlar, kişilere karşılıklı sağladığı avantaj noktasında, kişilerin doğrudan tanıdıklarıyla çalışmasının yanında bağlantıları vasıtasıyla tanıdıklarıyla da beraber çalışma imkânı sunar. İnsanların hayat şartlarının iyileştirilip geliştirilmesinde bu bağlantıların kullanılması önem arz etmektedir.

Gündelik hayatta sürekli olarak kişiler arasında sınırsız iletişim meydana gelmektedir. İletişim aslında, kişide ve sosyal yapılarda zenginlik değildir; kişisel etkileşimle meydana getirilen bağlantılar ve ağlar ile zenginleşerek oluşan sosyal sermayeye yönelik bir göstergedir. Bu sebeple sosyal sermaye toplumların ve/ya örgütlerin/organizasyonların sahip oldukları hazır sermayeden öte örgütsel/organizasyonel yapılarda üretilme ve geliştirilme imkânına sahip bir değerdir (Ekinci, 2010: 13).

Fukuyama ise sosyal sermayeyi, kişiler arasında bulunan harmoni ve işbirliğine destek sağlayan, samimiyetin hâkim unsur olduğu normlar topluluğu şeklinde tanımlayarak; sosyal sermayenin tek başına hareket eden veya girişimde bulunan kimseler vasıtasıyla oluşmadığını ileri sürmekte ve kişisel erdemlerden öte sosyal erdemlere dayalı olduğunu belirtmektedir (Aslan, 2012: 50; Ören, 2007: 73).

Sosyal sermaye konusunda Putnam, Bourdieu ve Coleman öne çıkmakta ve her biri farklı alanlarda sosyal sermayeye değinmiştir. Sosyal sermayeyi Bourdie sosyolojide, Coleman eğitim sosyolojisinde, Putnam siyaset biliminde ve Fukuyama ise iktisat tarihinde ve iktisat sosyolojisinde ele almıştır. Bu farklı görüşler aşağıdaki tabloda gösterilmiştir.

Tablo 1: Sosyal Sermaye ile İlgili Görüşlerin Karşılaştırılması

\begin{tabular}{|l|l|l|l|}
\hline & Tanımı & Amaç & Analiz \\
\hline Bourdieu & $\begin{array}{l}\text { Grup mallarına ulaşımı } \\
\text { sağlayan kaynaklardır }\end{array}$ & $\begin{array}{l}\text { Ekonomik sermayeyi güvence } \\
\text { altına almak }\end{array}$ & $\begin{array}{l}\text { Sinıf rekabeti içerisinde olan } \\
\text { bireyler }\end{array}$ \\
\hline Coleman & $\begin{array}{l}\text { Bireylerin amaçlarına ulaşmak } \\
\text { için kullanabilecekleri sosyal } \\
\text { yapının yönleridir }\end{array}$ & $\begin{array}{l}\text { Beşeri sermayeyi güvence } \\
\text { altına almak }\end{array}$ & $\begin{array}{l}\text { Aile ve toplum içerisindeki } \\
\text { bireyler }\end{array}$ \\
\hline Putnam & $\begin{array}{l}\text { Ortak yarar için birlikteliği } \\
\text { klişki ağlıan güven, normlar ve }\end{array}$ & $\begin{array}{l}\text { Etkin demokrasiyi güvence } \\
\text { altına almak }\end{array}$ & Ülke içerisindeki bölgeler \\
\hline
\end{tabular}

Kaynak: Akçay, 2005: 203

Maddi değere sahip kaynakların kullanılması ile fiziki sermaye üretilirken; beşeri sermayeyse, bilgi, beceri ve yetenek benzeri maddi olmayan unsurların geliştirilmesi ile üretilebilmektedir. Son zamanlarda fiziki ve beşeri sermayeyle beraber ele alınmaya başlayan sosyal sermaye ise, diğer sermaye türlerinden farklı olarak çıtıları kıymet kazanan daha soyut bir sermaye tipidir. Sosyal sermaye toplumun beklentilerinin performansının temel belirleyicisidir. (Gerşil ve Aracı, 2011: 42-43). Sosyal sermayenin önemini belirtirken, sadece sermaye kavramını ele alarak ekonomik alanla sınırlı tutmak yanlış olacaktır. Sosyal sermayenin, iktisadi alandaki olumlu etkilerinin ortaya çıkmasından önce; toplumsal, kültürel ve politik alanlarda güvenli bir sosyal yapının oluşunda önemli rol oynadığı görülmektedir Bu noktada sosyal sermayenin insan 
için ne kadar önemli olduğu, varlığının ve yokluğunun diğer unsurlarla kıyaslanmaması gereken bir olgu ortaya çıkmaktadır (Karagül, 2012: 99)

Toplumlardaki kurum, örgüt ve grupların, ortak amaçları ile ilkelerini belirleyebilmesi ekonomik ve sosyal gelişmeyle ilgilidir. Ortak amaçların ve ilkelerin belirlenebilme kabiliyeti, toplumun sahip olduğu sosyal sermaye birikimini göstermektedir. Sosyal sermaye seviyesi yüksek kişilerin, kurumların veya sivil toplum örgütlerinin beraber hareket yeteneklerini kullanması ile verimli çalışma ortamı oluşacaktır. Bu noktada, sosyal sermayenin oluşturulmasiyla ortak amaç çerçevesinde beraber harekete etme/geçme yeteneğini arttıran kolektif kurum kimliği oluşturulabilir (Tüysüz, 2011: 35-36).

\subsection{Müşsteri İlişkileri}

Müşteri ilişkileri kavramı tanımlanırken öncelikle müşteri, müşteri odaklı olmak ve müşteri sadakatine değinmek gerekmektedir. Müşterinin tanımlaması yapılırken kısaca; kişisel ve ticari hedefleri amacıyla ürün ve/ya hizmet satın alan kişiler ve/ya kuruluşlardır. Pazarlamanın, satışın, üretimin, hizmetin, zamanın, kaynak dağılımının ve karlılığın odağında müşteri bulunmaktadır. Odak noktası olarak müşteriyi kullanan işletmelere göre müşteriler kullanım amacı ve özellikleri açısında değerlendirilmektedir. Kullanım amacına göre dört farklı şekilde müşteri değerlendirilmesi yapılabilir. Bunlar; iç müşteri, dış müşteri, B2B (İşletme İşletme) müşteriler, Kanal - Dağıtıcı - Bayi - Franchise (Demirören, 2009: 12)

Pazarlama yönetiminin evrimsel sürecine bakıldığında işletmelerin müşteri odaklı olmaya doğru evirildiği görülmektedir. Bu evrenin ilk aşaması olan üretim anlayışı evresinde; üretim ve arzın yetersizliği nedeni ile müşteri bulmak ikinci sırada kalmış, daha ziyade bulunabilirlik, geniş dağıtım ağı ve verimlilik ön plana çıkmıştır. Ardından gelen ürün anlayışı evresinde kalite, yüksek performans ve yenilik içeren ürünler ön plana çıkmıştır. Satış anlayışı evresinde amaç satış artırmak olmuş ve aktif satış ve tutundurma faaliyetleri ön plana çıkmıştır. Daha sonra gelen dönem olan pazarlama anlayışı evresinde müşteri iyicene işletmeler tarafından odağa konmuş ve tüketicilerin gereksinimleri değerlendirilerek, bunları karşılamaya yönelik ürün ve hizmet üretilmesi ön plana çıkmıştır. Buradaki amaç rakiplere göre daha yüksek tüketici değeri yaratılarak ürün sunmak olmuştur (Eser ve diğerleri, 2011: 15-28). Daha genel bir tanım yapılacak olursa; müşteri ilişkileri yönetimi, bir yönetim stratejisidir. Müşteriyi merkeze alan stratejiler ve bunu destekleyen fonksiyonların yani satış ve pazarlamanın, müşteriye yönelik hizmetlerin, muhasebenin, üretim ve lojistiğin dikkate alındığı süreçler ile bu fonksiyonlardan etkilenen tüm birimler ve/ya iş grupları için teknolojinin de yardımı ile iş süreçlerinin yeniden düzenlenmesidir (Aktepe ve diğerleri, 2015: 2).

Pazarda sürekli artarak büyüyen rekabet baskısı, ürünlerin gittikçe birbirlerine benzemesi, ürün ve hizmetin farklılaştırılmasındaki zorluklar, karın giderek azalması işletmelerin pazarlama bölümlerini yapılandırmaya itmiştir. Mevcut müşterinin devamlılığının önemli olduğu günümüzde müşterilerin sadakatini ve sürekliliğ̈ini sağlamak için birçok teknik ve yöntem kullanılmaktadır. Öne çıkan yöntem ise müşteriyi odağına alıp müşterilerin memnuniyetini aşmayı amaç edinen yaklaşımdır. Bu yaklaşımla pazar payından ziyade müşteri payının öne çıkması sağlanmaktadır. Müşteri payı ile kast edilen müşterinin aktif hale getirilerek birden fazla ürünün satılabilmesidir (Arabacı, 2008: 90).

Müşteri ilişkileri yönetimi uygulayan işletmeler müşterilerin ihtiyaçlarını tanımlayarak strateji belirlemektedirler Müşteri ilişkileri yönetimi uygulamanın işletmelere bir takım katkıları ortaya çıkmaktadır (Bakırtaş, 2013: 7);

- İşletmede atıl vaziyetteki iş potansiyellerinin tanımlanması yapılır,

- İhtiyaç duyulan teknolojiler ve iş alanları belirlenir,

- Tedarikçi analizi yapılarak güçlü ve zayıf noktalar belirlenir,

- Tedarikçilerden geri besleme sağlanır,

- Rakipler hakkında yeni bilgilere ulaşılarak geri besleme sağlanır,

- Kıyaslama imkânı elde edilir,

- Müşteri ve tedarikçi arasındaki etkileşim hakkında bilgi elde edilir,

- Müşteriyi odağa alan faaliyet planları yapılmasına olanak sağlanır. 


\section{Yöntem}

\subsection{Araştırmanın Amacı}

Sosyal sermaye ile ilgili yapılan araştırmaların ağırlıklı olarak sosyal sermaye teorileri, türleri, düzeyleri, getirileri, ekonomik etkileri, kaynakları ve inşası üzerine olduğu gözlenmiştir. Bununla birlikte sosyal sermayenin müşteri ilişkileri üzerine etkileri konusunda yapılmış bir araştırmaya ise rastlanamamıştır. Müşteri ilişkilerinin önemi düşünüldüğünde; sosyal sermayenin müşteri ilişkilerine etkileri ile kişisel satışta sonuca ulaşmak ve başarıyı elde etmek de önem kazanmaktadır. Putnam’a göre (2000: 19), sosyal sermaye, toplumsal iş birliğinin önündeki engelleri kaldırma işlevi görmektedir. Bu noktada müşteriler ile ilk irtibat kurma imkânının oluşturulması veya kanalının açılması ve irtibat sonrası ilişkilerin geliştirilerek satışın sonuçlandırılması en temel amacı oluşturmaktadır.

$\mathrm{Bu}$ araştırmada aşağıdaki sorulara cevap aranmıştır.

- Müşteri ilişkileri sürecinde sosyal sermayenin etkisi nedir?

- Kişisel satış yapan personelin sosyal sermayesinin müşterilerin satın alma davranışlarına etkisi var mıdır?

Yukarıdaki sorulara aranan cevaplardan, kişisel satış alanında sosyal sermayenin müşteri ilişkileri üzerinde olumlu ve olumsuz etkilerinin tespit edilmesi ve sosyal sermayenin kişisel satış yoluyla pazarlama faaliyeti yürüten işletmeler için ne düzeyde etkili olabildiğinin tespit edilmesi ve sonuçlarının işletmeler için referans bir kaynak oluşturması amaçlanmaktadır.

\subsection{Araştırmanın Modeli}

Tarama modeli daha öncesinde ve hali hazırda mevcut olan durumun, olduğu şekilde betimlenmesini amaç edinen araştırma yaklaşımıdır. Araştırmaya konu teşkil eden durum, kişilerin veya olayların içinde bulundukları mevcut şartlarda ve olduğu şekliyle tanımlanmasına çalışılır. Bilinmek istenen bir durum vardır ve bu en uygun şekilde gözlemlenip belirlenmeye çalışılmaktadır (Büyüköztürk vd., 2017:24). Bu noktada bu araştırmada kişisel satış, sosyal sermaye ve müşteri ilişkileri kavramlarının tanımları yapılarak bu unsurların birbirleri ile ilişkileri ele alınarak sosyal sermayenin kişisel satış ve müşteri ilişkileri üzerinde etkilerine değinilerek Türkiye'de madeni yağ sektöründe faaliyet gösteren kişisel satış yapan bireyler ile mülakatlar gerçekleştirilmek suretiyle bir uygulama yapılmıştır. Araştırma süreci sonunda elde edilen veriler betimseldir ve içerik analizine tabi tutulmuştur. Betimsel analizle görüşme yapılan bireyleri tanıtıcı bulgular değerlendirilmiş, içerik analizi yoluyla veriler tanımlanmaya çalışılmış; birbirine benzediği ve birbiri ile ilişkisi olduğu tespit edilen veriler belirli kavramlar ve temalar çerçevesinde bir araya getirilerek yorumlanmıştır. İçerik analiziyle katılımcıların görüşlerinin içerikleri sistematik olarak tanımlanmaktadır.

$\mathrm{Bu}$ araştırmada araştırmacının istediği verilerin mülakat yapılan yöneticilerde olduğu, yöneticilerin istenilen bilgileri samimi ve gönüllü olarak verdiği ve konu hakkında bilgi sahibi oldukları ile verilen cevapların karşılaştırılabilir olduğu varsayılmıştır.

\section{3. Çalışma Grubu ve Özellikleri}

$\mathrm{Bu}$ araştırmanın çalışma grubunu madeni yağ sektöründe faaliyet gösteren firmalarda çalışan ve doğrudan satış yapan bölge müdürü pozisyonundaki satış personeli oluşturmaktadır. Madeni yağ sektörünün yapısı gereği doğrudan satışın sektördeki tüm firmalar tarafından kullanılan bir yöntem olması satış yetkililerinin araştırma konusu ile doğrudan ilgili olduğu gerçeğini ortaya çıkarmaktadır. Görüşme yapılan tüm çalışanlar erkek olup, firmalarda bölge müdürü pozisyonunda bulunan kadın çalışana rastlanmamıştır.

Araştırma grubunda bulunan tüm firmaların satış personelinin tamamına ulaşmak mümkün olmamıştır. Bu çerçevede 14 firma içinde görüşülen 6 firma evrenin \% 43'ünü oluştururken, bu örneklemi oluşturan firmaların yaklaşık pazar payı \% 93'dür. Pazarın yaklaşık \% 93'üne hitap eden bu 6 firmada doğrudan satış yapan bölge müdürü pozisyonundaki personelle görüşülmüştür. Örneklem verisi, her firmadan ortalama 3 satış personeli ile görüşülerek elde edilmiştir. Daha fazla kişi ile görüşmeye çalışılmış ancak deneklerin bir kısmının görüşmek istememesi, bir kısmına ulaşılamaması ve seyahatleri nedeni ile bir araya gelinememesi gibi sebeplerle toplamda 18 kişi ile görüşme sağlanmıştır. Her firmadan farklı bölgelerde görevli Bölge Satış Müdürü görevinde bulunan ortalama üçer kişi ile görüşme sağlanarak elde edilen verinin homojen dağılımı 
hedeflenmiştir. Mülakat yapılan firma yetkilileri ve çalıştıkları firmaları ifşa edilmesi ticari kaygı doğuracağı endişesi ile kişiler ve firmalar maskelenmiştir.

\section{4. Çalışma Verilerin Toplanması}

Madeni yağ sektörünün hitap ettiği yüksek miktarda yağ tüketiminin/kullanımının olduğu sanayi kuruluşları, inşaat, lojistik ve enerji sektörlerinde faaliyet gösteren firmaların toplu alım ve/ya sözleşme yöntemi ile satın alma faaliyeti yürütmektedirler. Bu noktada müşteriler ile birebir satış faaliyeti yürütme gerekliliği ortaya çıkmaktadır ve yoğun bir şekilde kişisel satış faaliyeti gerçekleşmektedir. Bu sebeple madeni yağ sektörü bu araştırmanın evreni olarak seçilmiştir.

Madeni yă̆ sektöründe faaliyet gösteren firmalarda çalışan doğrudan satış yapan bölge müdürü pozisyonundaki 18 adet personelle mülakat şeklinde görüşmeler gerçekleştirilerek veri toplanmıştır. Görüşme yapılan kişilerin farklı bölgelerde görev yapmaları ve farklı lokasyonlarda ikamet etmelerinden dolayı birebir mülakatların gerçekleştirilmesi Kasım 2018 ile Mayıs 2019 ayları arasında gerçekleştirilebilmiştir. Katılımcılarla yapılan görüşmeler yapılırken süre kısıtı konulmamış, uzun ve karş1lıklı görüşme şeklinde gerçekleşmiştir. Her bir görüşme ortalama 2 saat kadar sürmüştür. Sorulan tüm sorulara tatmin edici cevaplar alınmasını müteakip katılımcıların ilave edecekleri herhangi bir şey olup olmadığı sorulmuş ve son sözleri de alınarak görüşme sonlandırılmıştır.

Araştırmada gerekli verilerin sistematik bir şekilde toplanabilmesi ve analiz edilebilmesi için mülakat soruları önceden hazırlanarak görüşülen tüm yetkililere aynı sorular sorulmuştur. Soru listesi hazırlandıktan sonra örnek olarak 3 satış temsilcisi ile görüşülerek soruların amacına hizmet edip etmediği ve analiz edilebilirliği noktasında değerlendirilmiş ve gerekli düzenlemeler yapılarak mülakat soru listesi tekrar oluşturulmuştur. Mülakat soru listesinde açık uçlu sorular sorularak araştırmaya katılanların kendine özgün yaklaşımları ve görüşleri tespit edilmeye çalışılmıştır. Alınan cevaplar not edilerek görüşme sonunda katılımcı ile tekrar verilen cevaplar kontrol edilerek analize tabi tutulmuştur. Analiz sırasında araştırmaya katılanların soru formu dışındaki bazı notları da ek bilgi olarak kullanılmıştır. Çapraz sorulara verilen cevapların tutarlılıkları ile diğer sorulara verilen cevaplar da özetlenerek derlenmiştir.

\section{Analiz, Bulgu ve Yorumlar}

\subsection{Araştırmaya Katılanlara Yönelik Bazı Tanıtıcı Bilgiler}

Mülakat için tespit edilen kişiler, sektörde faaliyet gösteren ve pazarın yaklaşık \% 93'ünü kapsayan firmaların bölge satış müdürleri olup müşteriler ile doğrudan iletişime geçerek sıcak satış gerçekleştiren firmaların personelidir. Toplamda görüşülen 18 kişi pazardaki firmaların \%43'ünü oluşturan 6 firmadan seçilmişlerdir.

Tablo 2: Örneklem Firmaların Pazar Payları

\begin{tabular}{|c|c|c|c|}
\hline $\begin{array}{c}\text { SIRA } \\
\text { NO }\end{array}$ & FİRMALAR & $\begin{array}{c}2018 \text { MADENI YAĞ PAZAR } \\
\text { PAYLARI }\end{array}$ & $\begin{array}{c}\text { GÖRÜŞME YAPILAN KIŞ่ } \\
\text { SAYISI }\end{array}$ \\
\hline 1 & A FİRMASI & $26 \%$ & 3 \\
\hline 2 & B FIRMASI & $24 \%$ & 3 \\
\hline 3 & C FİRMASI & $17 \%$ & 3 \\
\hline 4 & D FİRMASI & $11 \%$ & 3 \\
\hline 5 & E FİRMASI & $8 \%$ & 3 \\
\hline 6 & F FİRMASI & $7 \%$ & 18 \\
\hline
\end{tabular}

Kaynak: PETDER, (2019) 
Mülakat yapılan katılımcıların \% 83'ü evli \% 17'si bekârdır. Katılımcıların tamamı lisans düzeyinde öğrenim görmüş olup, bunlardan birisi ayrıca yüksek lisans mezunudur. Bulundukları firmada bölge müdürü görevinde olan katılımcıların \% 22'si 21-30 yaş aralığındadır. En yüksek orana sahip yaş aralığ $\% 50$ ile 31-40 yaş grubudur. Kalanlar ise \% 28 ile orta yaş üstü olan 41-50 yaş grubunu temsil etmektedir. Firmada çalışılan sürelere bakıldığında çalışanların ağırlıklı olarak \% 72 ile 0-3 yıl grubuna dâhil olduğu görülmektedir. Diğer 4-6 yıl arası çalışanlar \% 17'lik kısmı oluştururken 7 yıldan fazla süredir çalışanlar ise \% 11'lik kısmı oluşturmaktadır. Madeni yağ sektöründe bölge satış müdürü görevinin gereği olan araçla seyahat zorunluluğu nedeni ile genelde enerji ve güç sahibi yaş grubu olan 31-40 yaş aralığındaki kişilerin bu pozisyonda çalıştığı gözlemlenmiştir. Katılımcıların her ay mutlak suretle şehir dışı seyahatleri olduğu ve zamanlarının çoğunun yollarda ve müşteri görüşmelerinde geçtiği ifade edilmiştir.

\subsection{Sosyal Sermayenin Müşteriler ile Kurulan İletişim ve İlişkilerdeki Etkileri ve Rolü}

Bölge Satış Müdürlerinin herhangi bir ihtiyaçlarını karşılamaya yönelik olarak sosyal çevrelerini kullanıp kullanmadıkları ve bu yönde ihtiyaç duyup duymadıkları kendilerine sorularak hangi sıklıkta sosyal çevrelerini kullanmaya eğilimli oldukları tespit edilmeye çalışılmıştır. Bu çerçevede sorulan 5nci soruya "Bir ihtiyacınız olduğunda tanıdık birisini arama ihtiyacı duyuyor musunuz?" ve "Evet ise ne sıklıkla arıyorsunuz?" verilen cevaplar incelenmiştir.

Katılımcılar ihtiyaçlarına yönelik olarak tanıdık birilerini arama yani sosyal çevresini kullanması noktasında \% 89 gibi bir oranla bu yönde bir eğilim göstermiştir. Sosyal çevresini arayanların da \% 56'sı her zaman, $\% 25^{\prime}$ i sık sık aradığını iletmiştir. \%19'lık kesim ise ara sıra aradığını belirtmiştir. Bu noktada katılımcılarda sosyal çevrelerini kullanma ihtiyacı duydukları ve bu yönde aksiyona geçtikleri görülmektedir.

Sosyal sermaye göstergelerinden olan grup üyeliğinin tespit edilmesi adına katılımcılara sorulan altıncı (Yeni müşteri ile ilk iletişime geçerken tanıdık birinden yardım (referans) alır mısınız?) ve yedinci (Daha önce iletişime geçilmemiş bir müşteri ile görüşürken sosyal çevrenizi kullanır mısınız? Evet ise ne sıklılar kullanırsınız?) sorular sorulmuştur. Altıncı soruda bölge satış müdürlerinin yeni bir müşteri ile ilk temasa geçerken tanıdık birilerinden referans alınması noktasında genel yaklaşım $\% 44$ oranı ile her zaman şeklinde olmuştur. \% 28 ile sık sık ve ara sıra tanıdıkların yardımı alındığı ifade edilirken \% 22 oranında ara sıra ve \%11 oranında nadiren tanıdık birinden yardım alındığı ifade edilmiştir. Yedinci soruda ise altıncı sorudan farklı olarak sosyal çevrenin kullanılması düzeyi tespit edilmeye çalışılmıştır. Yedinci soru ile üye olunan bir takım dernek, grup, hatta bir spor takımı veya o takıma ait kombine sahibi olmak gibi aktivitelere katılım sonucu bir gruba aidiyetin ve o grupların isimlerinin ve etkilerinin kullanılmasını ölçmeye yönelik veri elde edilmeye çalışılmıştır. Bu noktada katılımcıların \% 39'u her zaman sosyal çevresini kullandığını ifade ederken, \%17'lik bir kesim sık sık ve yine \% 22'lik kesim ara sıra kullandığını ifade etmiştir. \%11'lık bir kesim ise nadiren kullandığını ifade ederken, yine \%11'lık bir kesim de hiç kullanmadığını ifade etmiştir. Burada katılımcıların \% 89'luk bir kısmının bir şekilde sosyal çevresini kullandığı görülmektedir. 6ncı soruya verilen cevaplarda ise tamamına yakınının referans kullandığı görülmektedir. Burada 9 nolu katılımcının ifadesi ile "... ne zaman bir potansiyel müşteriye ulaşmada zorluk yaşasam ya ortak tanıdık arıyorum ya da sosyal medya üzerinden bağlantı kuruyorum ve mutlaka bir şekilde iletişime geçebiliyorum." şeklindeki cevabı bu yaklaşımı net bir şekilde ifade etmektedir. Katılımcılar yeni bir müşteri ile görüşme yapmadan önce eğer varsa ve faydalı olacağına inanıyorsa yapılan görüşmenin seyrine göre referanslarını gündeme getirdiklerini iletmişlerdir. Ayrıca sosyal çevrenin de eğer müşteriyi etkileme imkânı var ise kullanıldı̆̆ı ifade edilmiştir. Katılımcılardan bir kişi ise sosyal çevresini kullanmayı doğru bulmadığını ifade etmiş ve hiç kullanmadığını belirtmiştir. Ancak karşılıklı yapılan görüşmede bağlı bulunduğu sosyal çevre (memleketi, tuttuğu takım vs) gibi unsurların müşteri ile yapılan görüşmelerde gündeme geldiğini bazen olumlu bazen de olumsuz tepki aldığını dile getirmiştir.

Sosyal çevrenin etkilerini ölçümlemeye yönelik olarak sorulan Sekizinci (Tanıdık insanların çoğalmasının hayatı kolaylaştırdığını düşünür müsünüz?) ve Dokuzuncu (Müşteri ile satıcının aynı gruba üye olmasının satış yapma ihtimalini artırması ile ilgili düşünceniz nedir?) sorular ve cevaplar incelendiğinde; katılımcıların \% 50'si tanıdık insanların çoğalmasının her zaman hayatı kolaylaştırdığını düşünmektedirler. Tanıdık insanların sık sık hayatı kolaylaştırdığını düşünen insanların oranı $\% 17$ olup ara sıra ve nadiren cevabını verenler ile \% 11 ile ayn orana sahiptir. Ayrıca \%11'lik bir kesim de tanıdık insanların hayatı kolaylaştırmadığını ifade etmektedirler. Dokuzuncu soru ile müşteriye satış yaparken aynı gruba üyeliğin 
satıcıya bir avantaj sağlayıp sağlamadığını anlamaya çalışılmış ve alınan cevaplarda \% 100 'lük bir oranla avantaj sağladığı görülmüştür. \% 39'lük kesim her zaman avantaj olduğunu ifade ederken, \% 22'lik oran ile ara sıra ve nadiren avantaj sağladığını düşünenlerin oranı aynıdır. \% 17'lik kesim sık sık satışta avantaj sağladığını düşünmektedir. Bu noktada 3 nolu katılımonın ifadesi ile “...eğer içeride (müşteride) ekipten (içinde bulunduğu sosyal grubu kast ediyor) birini bulursam işler çok kolay yürüyor..." ifadesi grup üyeliğinin avantajını belirtmektedir. Verilen cevaplarda her ne kadar tanıdık çevrenin hayatı kolaylaştırdığı yönünde nadiren ve hiç cevapları verilse de görüşmelerde aslında katılımcıların sosyal çevrelerini genişletmek gibi bir eğilimde oldukları da görülmüştür.

Sosyal çevrenin müşteri ilişkileri üzerine etkilerini tespit etmeye yönelik sorulan Onuncu (Müşteriler ile kurulan iletişimde sosyal çevre etkili midir?) ve On Birinci (Müşteriler ile kurulan ilişkinin sağlıklı ve başarılı olmasında sosyal çevre etkili midir?) sorular ve alınan cevapların incelenmiştir. Yapılan görüşmelerde müşteriler üzerinde sosyal çevrenin etkili olup olmadığı araştırılmış ve alınan cevaplar değerlendirildiğinde \% 33'lük bir kesim her zaman etkili olduğunu ifade ederken, sık sık etkili olduğunu ifade edenlerin oranı da aynı şekilde \% 33'tür. Ara sıra etkili olduğunu iade eden 2 kişi \% 11'lik kısmı oluşturmaktadır. 3 kişi nadiren etkili olduğunu ifade ederken \%17'lik bir orana sahip olup, 1 kişi de hiç etkisi olmadığını ifade ederek \% 6'lık kısmı oluşturmaktadır. 11nci soruda cevabı aranan müşteri ile kurulan ilişkinin başarısındaki sosyal çevre etkisi incelendiğinde her zaman etkili olduğunu ifade edenlerin oranı \% 28 iken, sık sık etkili olduğunu ifade edenlerin oranı ise \%44'tür. Ara sıra ve nadiren etkili olduğunu belirten 2'şer kişi toplamda \%22'lik bir kesimi oluşturmaktadır. Yine 1 kişi etkisi olmadığını ifade ederek \% 6'llk bir orana sahip olmaktadır. Bu noktada 18 nolu katılımoının ifade ettiği "... iş ile ilgili sıkıntıların aşılmasında zaman zaman karşımdaki insanı etkileyeceğini düşündüğüm kişileri araya sokarak sonuç aldığım durumlar olmuştur." ifadesi sosyal çevrenin etkisini gözler önüne sermektedir. Bu sonuçlara göre sosyal çevrenin hem müşteriler ile kurulan iletişimde hem de ilişkide önemli bir yere sahip olduğu görülmektedir. Sorunların çözümünde ve görüşme sırasında doğru frekansın belirlenmesinde karşılıklı olarak bağlı bulunulan veya üye olunan sosyal grupların görüşmenin seyrini etkilediği katılımcılar tarafından ifade edilmiştir

Sosyal sermaye oluşumunda önemli bir yere sahip olan sosyal iletişim ağlarının ve sosyal grupların müşteri yani iş üzerinde etkisi olup olmadığını tespit etmeye yönelik olarak sorulan On İkinci (Sosyal iletişim ağlarını kullanır mısınız? Evet ise ne sıklıklar kullanırsınız?), On Üçüncü (Kullanılan sosyal iletişim ağlarının iş açısından olumlu bir katkısı olduğunu düşünüyor musunuz?) ve On Dördüncü (Müşteriler ile olan ilişkide sosyal gruplara üyeliklerin etkisi olduğunu düşünüyor musunuz?) sorulara verilen cevaplarda bir paralelliğin söz konusu olduğunu tespit edilmiştir. Katılımcılara On İkinci soruda sosyal iletişim ağlarının kullanılıp kullanılmadığı ve eğer kullanılıyorsa ne sıklıkla kullanıldığı sorulmuştur. Alınan cevaplarda tüm katılımcıların sosyal iletişim ağlarını kullandığı görülmüss ve $\% 50$ oranında sık sık kullandıklarını belirtmişlerdir. Katılımcıların \% 22'si her zaman sosyal iletişim ağını kullandığını belirtirken \% 17'lik bir kesim de ara sıra kullandığını ifade etmiştir. Nadiren kullananların oranı ise \% 11 olup hiç kullanmayan kimse yoktur. Katılımcılardan 3, 4, 13 ve 16 nolu kişiler "... müşteriye ulaşırken sosyal medya bağlantılarımı sık sık kullanmaktayım." şeklindeki ifadeleri sosyal iletişim ağlarının etkisini ortaya net bir şekilde koymaktadır. On Üçüncü soruda sosyal iletişim ağlarının iş açısından olumlu bir katkısı olup olmadığı tespit edilmeye çalışılmıştır. Katılımcıların \% 39'u her zaman olumlu bir katkısı olduğunu ifade ederken \% 28'lik kesim ise sık sık olumlu katkısı olduğunu belirtmiştir. Ara sıra ve nadiren olumlu katkısı olduğunu düşünenlerin sayısı 5 kişi olup toplamda \% 33'lük bir dilimi oluşturmaktadır. Müşteriler ile olan ilişkide sosyal gruplara olan üyeliklerin etkisini tespit etmeye yönelik sorulan On Dördüncü soruda \% 56 oranında her zaman etkisi olduğu ifade edilirken \% 11'lik kesim sık sık etkisi olduğunu ifade etmiştir. Ara sıra ve nadiren etkisi olduğunu ifade edenlerin toplam oranı ise \% 33'tür. Bu çerçevede katılımcıların tamamı sosyal grupların müşteri ile olan ilişkilerde etkisi olduğunu ifade etmişlerdir. Bu noktada da sosyal grup üyeliklerinin önemi ortaya çıkmaktadır.

Katılımcılara sorulan grup üyeliklerinin etkileri ile ilgili soruların ardından müşteriler nezdinde önemli olan grup üyeliklerini tespit etmek amacıyla On Beşinci soruda üye oldukları gruplar sorulmuştur. Alınan cevaplardan elde edilen bulgularda müşteriler nezdinde en etkili olan gruplar iş arkadaşı ile meslek grupları önce çıkmaktadır. Ardından okul arkadaş grupları, sosyal medya grupları, akraba grupları ile kültürel ve sosyal aktiviteler ile dernek, vakıf grupları gelmektedir. Katılımcıların bir kısmı gönüllü olmayarak da olsa 
bazı gruplara üye olduğunu ve bunun kendisine hem iş hem de özel hayatlarında kolaylıklar sağladığını ifade etmişlerdir.

Sosyal sermaye düzeyini ölçmeye yönelik olarak On Altıncı (Herhangi bir sivil toplum kuruluşuna üyeliğiniz var mıdır?), On Yedinci (Son bir yılda iş çevrenizde yapılan aktivitelere (piknik, gezi, vs) katılım düzeyiniz nedir?), On Sekizinci (Son bir yılda iş dışındaki çevrenizde yapılan aktivitelere (piknik, gezi, vs) katılım düzeyiniz nedir?) ve On Dokuzuncu (İş dışında arkadaşlarınızla ne sıklıkla görüşürsünüz?) sorular katılımcılara yöneltilmiştir. Toplumsal organizasyonlardaki yaşam düzeyini belirlerken dikkate alınan katılım, gönüllülük, sosyal adanmışlık ve sorumluluk kriterlerine yönelik sorulan sorulara verilen cevaplar derlenmeye çalışılmıştır. Mülakattaki On Altıncı soruda katılımcılardan her hangi bir sivil toplum kuruluşuna üye olup olmadıkları sorulmuştur. Katılımcıların yarısı üye olduğunu belirtirken diğer yarısı da her hangi bir üyeliğinin olmadığını ifade ederek eşit bir dağılım göstermiştir. On yedinci soruda sorulan son bir yılda iş çevrenizde yapılan organizasyon aktivitelerine (piknik, gezi, vs) katılım ile ilgili soruya verilen cevaplar incelendiğinde birbirine yakım bir dağılım olduğu görülmektedir. \% 22 ile her zaman, ara sıra ve nadiren cevabını verenler eşit oran almışlardır. \% 18'lik bir kesim ise sık sık katılım sağladığını ifade etmiştir. On sekizinci soruda ise iş dışındaki çevrenin yaptığı organizasyonlara katılım düzeyinde her zaman katılırım diyenler \% 11'lik kısmı oluştururken, \% 33'lük kesim sık sık katılım sağladığını ifade etmiştir. Ara sıra katılım sağlayanların oranı \% 22 iken nadiren katılanların oranı \%17' dir. \%17'lik bir kesim ise hiç katılım sağlamadığını ifade etmiştir. Her iki soru birlikte analiz edildiğinde iş çevresi ile ilgili yapılan aktivitelere bir şekilde katılım sağlanmakta olduğu görülmektedir, ki bu oran \% 94'tür. İş dışında ise aktivitelere katılım biraz daha düşerek \% 83 seviyesinde gerçekleşmektedir. Yapılan ikili görüşmelerde katılım sağlamak istemeyenlerin daha ziyade yalnız kalmak, yorgunluk ve kendisine zaman ayırmak gibi gerekçeleri olduğu ifade edilmiştir. Katılım sağlayanlar ise sosyalleşmek ve sevdikleri ile birlikte olmak istediklerini belirtmişlerdir. Bu noktada sorulan on dokuzuncu soruya verilen cevaplar bu ifadeleri teyit etmektedir. Katılımcıların \%22'lik bir kesimi iş dışında arkadaşları ile her zaman görüştüğün belirtmişlerdir. Diğer taraftan \%44'lük bir kesim de sık sık görüştüğümü ifade etmiştir. Ara sıra ve nadiren görüştüğünü belirtken katılımcılar aynı \% 17 ile aynı oranda olup, hiç görüşmediğini ifade eden kimse olmamıştır. Bu üç soruya verilen sorulardan görüldüğü üzere katılımcılar sosyalleşme ihtiyaçlarını hem iş hem de iş dışı arkadaşları ile sağlamaktadırlar.

Sosyal sermayenin önemli parametrelerinden bir tanesi olan güven düzeyinin tespitine yönelik olarak sorulan Yirminci (Aynı sinıf/rrk/din/ ya da etnik gruptaki insanlara ne düzeyde güvenirsiniz?) ve Yirmi Birinci (Farklı sınıf/rk/din/ ya da etnik gruptaki insanlara ne düzeyde güvenirsiniz?) sorular ve cevapların derlenmiş ve analiz edilmiştir. Analiz sonuçlarına göre; aynı sınıf/din ya da etnik gruba üye olunması kişilerde güven düzeyini \% 56 seviyesine çekmektedir. Kararsız olanların oranı ise \% 33 olmaktadır. Güvenmeyenle ise \% 11'lik kesimi oluşturmaktadır. Bu noktada 8 ve 14 nolu katılımcıların ifade ettiği “... aynı frekansta olduğum yani değer yargılarımızın uyuştuğu, dini hassasiyetimizin yakın olduğu kişilerle daha rahat ilişki kurabiliyorum." ifadesi bu durumu ortaya koymaktadır. Aynı soru farklı sınıf/din ya da etnik gruplar için sorulduğunda dramatik bir şekilde güven düzeyi \% 22'ye düşmektedir. Kararsızların ve güvenmeyenlerin oranı artarak \% 39 ile aynı düzeyde görülmektedir. Karşılıklı yapılan görüşmelerde kişiler karşılarındakilerinin kendilerine güvenmesini beklerken kendileri güven duymadıklarını ifade etmişlerdir. Sebepleri olarak da daha önce yaşadıkları tecrübelerden dolayı karşılarındakilere olan güvenlerinin sarsıldığını ifade etmişlerdir. Görüşmelerde edinilen izlenim, bu güvensizliğin kişilerin kendileri ile ilgili açık vermeleri durumunda karşılarındakilerin bunu kullanma ihtimaline karşı oluşmaktadır. Her ne kadar kendileri karşısındakinin açı̆̆ını avantajına kullanmayacaklarını ifade etseler de ticari ilişkilerde bu durumu zaman zaman fırsata dönüştürdüklerini belirtmişlerdir.

Katılımcıların iletişim ve tanışıklık durumu ile çevreleri arasındaki bilgi alış verişinin tespit etmeye yönelik olarak sorulan Yirmi İkinci (çevreniz ile farklı konularla ilgili bilgi alışverişinde bulunma düzeyiniz nedir?), Yirmi Üçüncü (ikamet ettiğiniz yerde ne düzeyde tanınırsınız?) ve Yirmi Dördüncü (ikamet ettiğiniz yerde çevredekileri ne düzeyde tanırsınız?) sorular sorulmuştur. Katılımcıların \% $44^{\prime}$ ü çevresi ile her zaman bilgi alış verişinde bulunduğunu ifade etmiştir. \% $28^{\prime}$ lik bir kesim ise sık sık bilgi alış verişinde bulunduğunu belirtmiştir. Ara sıra ve nadiren bilgi alış verişinde bulunanların toplam oranı ise \% $28^{\prime}$ dir. Görüldügüü üzere katılımcıların tamamı çevresi ile bilgi alış verişinde bulunmaktadır. Bilgi alış verişinin yanında kişinin çevresinde ne düzeyde tanındığı sorulmuştur. Herkes tanır diyenler \% 22'lik bir kısmı oluştururken \% 50'lik 
bir kesim ise önemli bir kesim tarafından tanındığını belirtmiştir. Az bir kesim tanır diyenler \% 22 oranında olup kimse tanımaz diyen 1 kişi \%6'lık bir orana sahiptir. Diğer katılımcılara benzer olarak 15 numaralı katılımonın "... bir ihtiyaç halinde etrafıma sorarak sonuca ulaşmanın en kestirme yol olduğunu çok tecrübe etmişliğim vardır." şeklindeki ifadesi çevre ile olan bilgi alış verişine verdikleri önemi ortaya koymaktadır. Katılımcının çevresini tanıma düzeyi de araştırmada 24üncü soru ile sorulmuş ve bir önceki soruya yani tanınma düzeyine verilen cevaplar ile benzer sonuçlar elde edilmiştir. Herkesi tanıyanların oranı \%22, önemli bir kısmı tanıyanların oranı \% 50, az bir kısmı tanıyanların oranı ise \% 22'dir. Aynı katılımı kimseyi tanımadığını ve tanınmadığını ifade etmiş ve \% 6'lık bir oranı oluşturmuştur. Çevrede tanınma ve tanıma düzeyi kişinin bulunduğu ortamda ikamet süresi ile bağlantılı olduğu yapılan görüşmelerde tespit edilmiş, ayrıca kişinin sosyal becerisi yani iletişim kurma ve ilerletme kabiliyetinin de etkili olduğu görülmüştür.

Sosyal sermayenin müşteriler ile kurulan iletişim ve ilişkilerdeki etkileri ve rolünü anlamaya yönelik sorulan sorularda ilk olarak katılımcıların sosyal çevrelerini kullanma ve bunun sonucu olarak sosyal çevrenin kişinin hayatında özellikle de iş hayatında ne düzeyde etkili olduğuna bakılmıştır. Ardından katılımcıların sosyal sermaye düzeyleri tespit edilmeye çalışılmıştır. Bu noktada katılımcıların güven düzeyleri ve sosyalleşme düzeyleri ile iletişim ve tanışıklık durumları incelenmiştir.

\subsection{Sosyal Sermaye Düzeyinin Müşteri İlişkilerinde Oluşturduğu Farklılıklar}

Bireylerin sahip oldukları sosyal sermaye düzeyine göre müşteri ilişkilerinin oluşturduğu farklılıkları tespit etme yönelik üzere ilk olarak Yirmi Beşinci (Hedef verilen performans kriterlerindeki son yıldaki başarı durumunuz nedir?), Yirmi Altıncı (Yeni kazanılan müşterinin mevcut müşteriye oranı yaklaşık olarak nedir?) ve Yirmi Yedinci (Son bir yıl içinde kaybedilen müşteri oranı yaklaşık olarak nedir?) sorular ile işlerindeki başarı durumları ortaya konulmaya çalışılmıştır. İlgili sorular ve verilen cevaplar incelendiğinde; katılımcıların hedefler konusundaki başarı durumları benzerlikler göstermektedir. Daha önce Altıncı ve Yedinci sorularda sorulan sosyal çevrenin kullanılması konusunda nadiren veya hiç kullanmıorum cevaplarını veren katılımcıların başarı düzeylerinde diğer katılımcılara göre düşüklük olduğu görülmektedir. Yine aynı katılımcıların sosyal sermaye tanıdık insanların ve grup üyeliğinin sağladığı avantajlar konusundaki verdileri cevaplar ile de örtüşmektedir.

Katılımcılara Yirmi Sekizinci soruda sorulan yeni müşteri kazanımındaki faktörlerin neler olduğu konusunda katılımcıların verdiği cevapları sosyal sermaye kriterleri açısından incelendiğinde öne çıkan faktörler referans, doğru kişi ile iletişim kurulması, randevu alabilmek, ikili ilişki, dürüstlük, güvenilir olmak ve sosyal çevre ön plana çıkmaktadır. Tüm bu özellikler çalışmanın konusu olan sosyal sermaye ile doğrudan ilişkili olup sosyal sermayenin hem müşteri ilişkilerine olan etkisi hem de sosyal sermaye düzeyinin müşteri ilişkilerini nasıl yönlendirdiği ile ilgili önemini ortaya koymaktadır. 8 numaralı katılımcının verdiği cevap "önemli müşterilerden randevuyu ancak bir aracı vasıtası ile alabiliyorum." randevu noktasında sosyal sermaye gücünü ortaya koymaktadır.

Katılımcıların Yirmi Dokuzuncu (Bir gruba üye olmanın sağladığı katkıları belirtiniz?) soruya verdikleri cevaplarda yani bir sosyal gruba üye olmanın sağladığı katkıları ifade ederken hem özel hem de iş hayatlarında farklı kapıların açıldığını ve sahip olunan maddi imkânların daha kolay ve kazanç getirecek şekilde yönlendirilmesinde fayda sağladığını belirmişlerdir. Bu durumu 11 nolu katılıcının “... derneğinde tanıştığım A firması yöneticisi yeni yatırımlarından bahsetti ve tüm rakiplerden önce teklif vererek işi bağladım" cümlesi çok güzel ifade etmektedir. Ayrıca kendileri ve çevreleri için ihtiyaç olması halinde iş bulmada kolaylık sağladığını; örneğin 3,6, 8 ve 10 numaralı katılımcılar üye oldukları meslek odasının bir toplantısında kendileri ve yakın arkadaşları için iş bulduğunu ifade etmiştir, zaman zaman problemlerin çözümlenmesinde sosyal çevrelerinin etki alanını kullandıklarını; örneğin 2 nolu katılımcı müşterisi ile olan ödeme problemini bir dernek yemeğinde tanıştığı firma çalışanı vasıtası ile çözdüğünü ifade etmiştir. Ayrıca içinde bulunulan sosyal çevrenin sağladığı manevi tatminin yanı sıra kişisel gelişim imkânı, bilgiye kolay erişim olanağı, iletişim kurmada sağladığı kolaylıklar ön plana çıkmaktadır. Bu noktada 6 ve 17 nolu katılımcı potansiyel müşterilerinin yatırımları hakkında bilgiye bir açılış organizasyonunda eriştiğini belirtmiştir.

Katılımcılara Otuzuncu soruda (Ticari faaliyette bulunulan işletmeler ile kurulan ilk iletişimin kaynakları nelerdir?) ticari faaliyette bulunulan işletmeler ile kurulan ilk iletişimin kaynakları sorularak müşteriler ile ilk kurulan temasta katılımcıların nasıl bir yol izledikleri tespit edilmeye çalışılmıştır. Bu sayede yöntem ve 
yaklaşımlarını yorumlama imkânı olacağı öngörülmüştür.1 Alınan cevaplarda, katılımcılar yeni bir işletme ile temas kurarken ilk teşebbüsleri genelde doğru kişiyi bulup randevu alabilmek şeklinde olmaktadır. Referans veya tanıdık bir kimse bularak bu seviye aşılmaya çalışılmaktadır. Buradan da görüldüğü üzere sosyal çevrenin yani sosyal sermayenin gerekliliği ortaya çıkmaktadır. Sosyal sermaye sahibi kimselerin daha kolay erişim ve iletişim sağladığı önceki sorulara alınan cevaplarda ifade edilmişti. Bu sorulara verilen cevaplarda sosyal sermayenin gerekliliğini ortaya koyduğu görülmektedir.

Katılımcılara sorulan Otuz Birinci soruda (Kişinin işle ilgili başarısında sosyal sermaye düzeyinin etkileri nelerdir?) kişinin işle ilgili başarısında sosyal sermaye düzeyinin olumlu etkileri hakkındaki düşünleri öğrenilmeye çalışılmıştır. Alınan cevaplarda sosyal sermaye düzeyinin ne kadar yüksek olursa etkisinin de genellikle yüksek olduğu ifade edilmiştir. Bu etkinin katılımcılar tarafında bir oranla ifade edilmesi istenmiştir. Aynı şekilde Otuz İkinci (Kişinin işle ilgili başarısızlığında sosyal sermaye düzeyinin etkileri nelerdir?) soruda da kişinin işle ilgili başarısızlığında sosyal sermaye düzeyinin olumsuz etkileri hakkındaki düşünleri öğrenilmeye çalışılmıştır. Alınan cevaplar da başarısızlığın nedeni olarak sosyal sermaye seviyesinin düşük olmasının etkisi olduğu söylenmesine rağmen başarıdaki olumlu etki kadar olumsuz etkiye sahip olmadığı ifade edilmiştir.

Yapılan görüşmelerde olumlu etkisi olduğunu ifade eden katılımcılar genelde aşağıdaki gerekçeleri öne sürerek bu kanıya vardıklarını belirtmişlerdir;

- Sosyal bağlantılar iletişim kurarken ve iş ilişkisinde müşteriye fayda sağladığı sürece olumlu katkı yapmaktadır,

- İş bağlantılarımı geliştirmek için sosyal sermayenin kullanıldığı durumlar olmaktadır,

- Randevu alınamadığı veya erişimde zorlanıldığı müşterilerde sosyal çevreden faydalanmak işe yaramaktadır,

- Eğer sosyal çevre vasıtası ile bir müşteri ilişkisi kurulmuşsa genellikle olumlu geri dönüş alınmaktadır,

- Sosyal çevrenin genişliği oranında müşterilerin bulunması ve iletişime geçilmesi kolay olmaktadır,

- Bir problemle karşılaşıldığında sosyal çevrenin müdahalesi ile çözüm kolaylaşabilmektedir,

- Müşteri görüşmelerinde referanslar hem randevu alırken hem de görüşme sırasında genellikle avantaj sağlamaktadır,

- Firmalarda doğru kişi ile doğru zamanda görüşebilmek ve iletişimin hızlı gerçekleşebilmesi noktasında olumlu katkı yapmaktadır.

Başarısızlıkta sosyal sermayenin etkisi olduğunu ifade eden katılımcılar ise aşağıdaki gerekçeleri ortaya sürerek bu kanıya vardıklarını ifade etmişlerdir;

- Zaman zaman müşteri tarafından bağlı bulunulan grup üyeliği farklı gerekçelerle (daha önce yaşanan tecrübe, iticilik, vs.) olumsuz karşılanabilmektedir,

- Randevu vermeyen bir müşteri ile sosyal çevre kullanılarak alınan randevu her zaman olumlu sonuçlanmayarak ters tepkiye neden olabilmektedir,

- Referans ile yapılan görüşmede müşterinin kendisini baskı altında hissetmesine neden olabilmekte ve bu da olumsuz sonuçlar doğurabilmektedir,

- Müşteriler genelde sosyal sermayesi yüksek (çevresi geniş) olan satıcılar ile görüşmeyi tercih edebilmektedirler,

Katılımcılara sorulan Otuz Üçüncü soruda (Kişinin iletişim halinde olduğu mevcut müşterinden kendisini diğer potansiyel müşterilere yönlendirmesini istemesi olağan mıdır? Neden?) kişinin iletişime geçtiği ve/ya satış yaptığı mevcut müşterisinden kendisini diğer potansiyel müşterilere yönlendirmesini beklemesinin/istemesinin olağan olup olmadığı ve nedeni öğrenilmeye çalışılmıştır. Bu soruda amaçlanan katılımcıların elde ettikleri sosyal sermayelerini artırma ve kullanma eğilimlerinin tespit edilmesidir. Katılımcıların verdiği cevaplar incelendiğinde katılımcıların tamamı müşterilerinden kendileri için referans olmasını beklemekte ve gerekli yönlendirmeyi yapmasını istemektedirler. 9 ve 14 nolu katılımcıların hemen hemen aynı kelimelerle belirttikleri “...tabii ki yönlendirme isterim ve genelde de olumlu tepki alırım” şeklindeki ifadeleri bu durumu çok net bir şekilde desteklemektedir. Bunun sebebini aşağıdaki gerekçelerle özetlemek mümkündür; 
- Sosyal sermayeyi artırmak,

- Kolay iletişim kurmak,

- Sorunların kolay ve hızlı çözümünü sağlamak,

- Sonuca hızlı ulaşarak satışı gerçekleştirmek,

- Rekabette avantajı ele geçirmek,

- Zamandan tasarruf sağlamaktır.

Mülakattaki son soruda katılımcılara sosyal çevrenin yönlendirmesi ile ilişki kurulan müşteriler ile her hangi bir yönlendirme olmadan iletişime geçilen müşteriler kıyaslandığında satışın gerçekleşmesi noktasında sonuca yönelik olarak olumlu ve olumsuz etkileri sorulmuştur. Alınan cevaplar bir tablo şeklinde özetlenerek aşağıda gösterilmiştir.

Tablo 32: Sosyal Çevrenin Müşteri İle Kurulan İlişkideki Etkileri

\begin{tabular}{|c|c|c|c|}
\hline \multicolumn{2}{|c|}{ Sosyal Çevre Yönlendirmesi İle Kurulan İlişki } & \multicolumn{2}{|c|}{\begin{tabular}{|c|c|} 
Sosyal Çevre Tarafından Herhangi Bir \\
Yönlendirme Olmadan Kurulan İlişki \\
\end{tabular}} \\
\hline Olumlu Etkileri & Olumsuz Etkileri & Olumlu & Olumsuz \\
\hline Randevu alma kolaylığı & $\begin{array}{l}\text { Satış yapanda ve } \\
\text { satın alanda } \\
\text { karşılıklı psikolojik } \\
\text { baskı hissedilmesi }\end{array}$ & $\begin{array}{l}\text { Doğrudan hedef } \\
\text { yönelik görüşmenin } \\
\text { gerçekleşmesi }\end{array}$ & Zaman kaybı \\
\hline Kolay iletişim imkanı & $\begin{array}{l}\text { Müşterinin aracı } \\
\text { kullanılmasına tepki } \\
\text { göstermesi }\end{array}$ & $\begin{array}{l}\text { Önyargılardan } \\
\text { bağımsız görüşme ve } \\
\text { karar imkanı sağlaması }\end{array}$ & $\begin{array}{l}\text { Rekabette tercih } \\
\text { edilmeme }\end{array}$ \\
\hline Bilgi paylaşım imkanı & $\begin{array}{l}\text { Karşılıklı gereksiz } \\
\text { taleplerin ortaya } \\
\text { çıması }\end{array}$ & $\begin{array}{l}\text { Konuya objektif } \\
\text { yaklaşma imkanı } \\
\text { sağlaması }\end{array}$ & $\begin{array}{l}\text { Düşük güven } \\
\text { düzeyi }\end{array}$ \\
\hline Bilgi paylaşım kolaylığı & $\begin{array}{l}\text { Satıcı ve alıcı } \\
\text { arasındaki } \\
\text { mesafenin } \\
\text { kaybolması }\end{array}$ & $\begin{array}{l}\text { Tarafların sürekli } \\
\text { birbirini tartması ve } \\
\text { tedbirli olunması }\end{array}$ & $\begin{array}{l}\text { Tarafların } \\
\text { görüşmelerinde } \\
\text { ihtiyatlı } \\
\text { davranmaları }\end{array}$ \\
\hline Pozitif ve yapıcı iletişim & $\begin{array}{l}\text { Görüşmelerin } \\
\text { gereksiz yere } \\
\text { uzaması }\end{array}$ & $\begin{array}{l}\text { Görüşmelerde net } \\
\text { kayıp ve kazançların } \\
\text { daha kolay ve objektif } \\
\text { analiz imkanı }\end{array}$ & $\begin{array}{l}\text { Karşı tarafa karşı } \\
\text { bir bariyer } \\
\text { oluşturma refleksi }\end{array}$ \\
\hline Uzun dönemli ilişki imkanı & $\begin{array}{l}\text { Her iki tarafında de } \\
\text { haksız beklentiye } \\
\text { girmesi }\end{array}$ & $\begin{array}{l}\text { Daha rahat görüşme } \\
\text { imkanı sağlaması }\end{array}$ & $\begin{array}{l}\text { Bilgiye erişim } \\
\text { zorluğu }\end{array}$ \\
\hline Sorunların kolay çözümlenmesi & & $\begin{array}{l}\text { Görüşmelerde gereksiz } \\
\text { konulardan uzak } \\
\text { durulması }\end{array}$ & $\begin{array}{l}\text { Bilgiye kısıtlı erişim } \\
\text { imkanı }\end{array}$ \\
\hline Sonuca yönelik iletişim & & & Randevu alamama \\
\hline Satışın gerçekleşmesi & & & \begin{tabular}{|l|}
$\begin{array}{l}\text { Doğru kişiye } \\
\text { ulaşamama }\end{array}$ \\
\end{tabular} \\
\hline Rekabette tercih edilme & & & Satışın uzaması \\
\hline
\end{tabular}

Yukarıdaki tabloda görüleceği üzere sosyal sermayenin müşteri ile kurulan ve yürütülen ilişkide sağladığ1 avantajların dezavantajlarla kıyaslandığında çok fazla olumlu katkı sağladığı ve sosyal sermayenin doğrudan satış yapan personellerin başarısın için gerekli olduğu ortaya çıkmaktadır.

\section{Sonuç ve Değerlendirme}

Kişisel satışta sosyal sermayenin müşteri ilişkileri üzerine etkileri üzerine olan bu çalışmada çalışanın sahip olduğu birçok özelliğin yanında sosyal sermayesinin işletmenin başarısında ve dolayısı ile kişinin 
başarısında ne düzeyde etkili olduğuna yönelik tespitler yapılmaya çalışılmıştır. Kişisel satış yapan yetkililerle yapılan mülakatlarda sosyal sermaye farkındalığına bakılmış ve sahip olunan sosyal sermayenin yaptıkları işlerdeki etkileri tespit edilmeye çalışılmıştır. Müşteri ile kurulan ilk temas öncesinden başlayarak müşteri ile ilişki kurulması ve sürdürülmesi sürecinde sosyal sermeye etkileri ve satış yetkililerinin sahip oldukları sosyal sermayelerinin hem müşteri ilişkileri üzerinde etkileri olduğu hem de sosyal sermaye düzeylerine göre müşteri davranışlarının farklılaştığı tespit edilmiştir. Literatürde de belirtilen kişisel satış temsilcisinin müşteri adaylarını belirlerken kullandığı yöntemler arasında bulunan aracıların kullanılması bu çalışmanın sonuçları da desteklemektedir.

Normal satış süreçlerinde alım kararlarının genelde anlık verildiği görülürken işletmeden işletmeye yapılan satışlarda müşterilerin karar verirken genellikle bir süreç sonunda yani farklı seviyelerdeki karar vericilerin kararlarına göre hareket edildiği görülmüştür. İşletmelerin ürün seçimlerindeki karar sürecinde kişisel satış temsilcisi ile kurulan ilişki ve bilgi alış verişinin müşterinin kararını doğrudan etkilediği tespit edilmiştir. Bu nedenle kişisel satış temsilcisinin önemi daha da ortaya çıkmıştır. Gerek daha önce yapılmış çalışmalarda gerekse bu çalışmada kişisel satış yetkilisinin sahip olduğu özelliklerinin müşteri ilişkileri noktasında ön plana çıktığı görülmektedir.

Kişisel satışın avantajlarını çevre edinmenin yani çevre sahibi olmanın bir diğer ifade ile sosyal sermaye sahibi olmanın satış temsilcisi için avantaj sağladığı görülmektedir. Bu çalışmada da bu avantajı doğrular nitelikte sonuçlar elde edilmiştir. Özellikle iş hayatında kullanılan sosyal sermayenin potansiyel müşterilerin tespiti ve bu tespitin ardından ilk temasın kurulması noktasında ihtiyaç duyulan bir unsur olduğu görülmüştür. Müşteriler ile ilk temas kurulurken sosyal çevreden yardım alındığı ve bu yardım ile müşteri ilişkileri yönetimi sürecinde müşteri seçimi aşamasında gereksiz kaynak harcanmasının önüne geçildiği görülmüştür. Müşteri ile ilk temas sonrası yürütülen ilişki boyunca müşteriler ile yaşanan ve/ya yaşanması muhtemel zorluklar noktasında sosyal çevrenin yardımının alındığı ve destek ile birlikte müşteri ilişkilerinde olumlu yönde adımların atıldığı tespit katılımcılar tarafından ifade edilmiştir.

Sosyal sermaye faktörünün müşteriler ile ilişkilerdeki etkin rolünün farkında olan katılımcıların bu faktörü etkin bir şekilde kullanma eğiliminde oldukları ve ihtiyaç duymaları halinde devreye soktukları görülmüştür. Bu noktada katılımcılar sosyal sermaye düzeylerini artırmaya yönelik olarak sosyal iletişim ağlarını kullandıkları, bir takım sosyal gruplara üye oldukları, katılım sağladıkları tespit edilmiştir. Yapılan mülakatlarda müşteri ile aynı sosyal gruba üye olmanın getirdiği avantajlar satış yetkilileri tarafından sıralanırken bir takım olumsuz etkilerle de karşılaşıldığı belirtilmiş̧ir. Ağırlıklı olarak olumlu etkilerden söz edilirken üye olunan bir grubun müşteride olumsuz bir etki bırakması olasılığı da göz ardı edilmemektedir. Bu nedenle katılımcıların sahip oldukları sosyal sermayelerini kontrollü olarak kullandıkları da söylenebilir. Bu yöntem ile kendilerine avantaj elde etmeyi amaçlamaktadırlar.

Çevresiyle uyumlu ve pozitif ilişkilere sahip, kendisini yetiştirmiş kimselerin koydukları hem kişisel hem mesleki hedeflerine ulaşmalarının daha kolay olduğu görülmektedir. Bu çalışmada satış temsilcisinde olması gereken özelliklere ilave olarak satış temsilcisinin sosyal sermaye gücünün de ilave edilmesi gerektiği ortaya çıkmıştır. Zira sosyal sermaye ile satın alımı gerçekleştiren işletme ve/ya işletme çalışanı için bir avantaj, kazanç sağlama imkânı doğabilmektedir ve işletmeler satın alma sürecinde satış temsilcisinin sahip olduğu sosyal sermayeden istifade edebilmektedirler. Sosyal sermaye bu yönüyle satış temsilcisi için satışın gerçekleşmesinde pozitif bir katkı sağlamaktadır. Bu özellik işletmelerin kişisel satış elemanı seçiminde belirleyici ve de önemli bir karar kriteri olması gerektiğini ortaya koymaktadır.

Elde edilen bulgular incelendiğinde katılımcıların sosyal sermaye için önemli bir faktör olan güven düzeyinin bulundukları sosyal çevrede daha yüksek olduğu ve de arttığı ancak farklı sınıf, ırk, din ya da etnik gruplarda düşük düzeyde olduğu görülmüştür. Bu noktada katılımcılar sosyal sermayelerini artırma eğilimi gösterirken güven açısından temkinli yaklaşım sergilemektedirler. Katılımcıların çevrelerindeki tanınmışlık düzeyleri ve çevrelerini tanıma düzeyleri arasındaki uyum sosyal sermaye kullanımları ile paralellik göstermektedir. Tanınmışlık düzeyi yüksek olanların sosyal sermayelerini artırmaya ve kullanmaya eğilimli oldukları ve kullandıkları görülmüştür. Bu noktada işletmelere düşen çalışanları için sosyal sermaye düzeylerini artırmasına imkân sağlayacak olanakları sunmasıdır.

Katılımcıların sıralamış olduğu yeni müşteri kazanımındaki önemli faktörlere bakıldığında referansın, doğru kişi ile iletişimin, güvenilirlik ve sosyal çevrenin ön plana çıtığ görülmektedir. Bu faktörler sosyal 
sermaye ile doğrudan ilişkili olup sosyal sermayenin hem müşteri ilişkilerine olan etkisi hem de sosyal sermaye düzeyinin müşteri ilişkilerini nasıl yönlendirdiğini ortaya koymaktadır. Katılımcılar, sosyal sermaye göstergesi olan bir gruba üye olmanın sağladığı katkıları sıralarken müşteri ilişkilerindeki olumlu katkılarının yanında kişisel olarak maddi imkanların kolay yönlendirilmesi, manevi tatmin (moral ve motivasyon), bilgiye erişim ve paylaşımda kolaylık, problemlerin çözümünde çare üretebilme kabiliyeti ve nihayetinde sürekli bir sosyal sermaye artışı sağladığı ifade etmektedirler. Katılımcıların sahip oldukları bu sosyal sermayelerini müşteriler ile ilk temas kurulması noktasında kullandıkları tespit edilmiştir. Sahip olunan sosyal sermaye düzeylerinin rekabette fark yarattığı da bu çalışmadan çıkarılacak sonuçlar arasında gösterilebilir. Zira yüksek yüksek sosyal sermaye seviyesine sahip bir çalışan hem işinde başarı noktasında hem de kişisel tatmin noktasında öne çıkmaktadır. Çalışmada sosyal sermaye düzeyi yüksek olan satış yetkililerin daha başarılı olduğu hedeflerin başarılması, müşteri kazanç ve kayıp noktasında ortaya çıkmaktadır. Ayrıca sosyal sermaye zenginliğinin kişide kişisel tatmin sağladığı katılımcılar tarafından ifade edilmektedir.

Yapılan analiz neticesinde çıkarılabilecek bir diğer sonuç da sosyal çevrenin yönlendirmesi ile ilişki kurulan müşteriler ile her hangi bir yönlendirme olmadan iletişime geçilen müşteriler kıyaslandığında satışın gerçekleşmesi noktasında sonuca yönelik olarak olumlu ve olumsuz etkileridir. Bu çerçevede araştırmadan sosyal sermayenin müşteri ile kurulan ve yürütülen ilişkide sağladığı avantajların dezavantajlarla kıyaslandığında çok fazla olumlu katkı sağladığı ve sosyal sermayenin doğrudan satış yapan personellerin başarısın için gerekli olduğu ortaya çıkmaktadır. Ayrıca dezavantaj olarak görülen unsurların avantaja dönüştürülebilme imkânı da olasıdır.

Bu çalışmada elde edilen sonuçlardan hareketle sosyal sermayenin müşteri ilişkileri üzerindeki etkilerine binaen işletmeler için yapılabilecek önerileri aşağıdaki gibi sıralamak mümkündür;

- İşletmeler için özellikle de satış personeli seçerken sosyal sermaye düzeyi yüksek ve/ya sosyal sermayelerini artırma kabiliyetine sahip adayları tercih etmesi gerekmektedir,

- Yapılan iş mülakatlarında sosyal sermaye düzeyini tespit ve geliştirmeye yönelik unsurlara önem verilmesi gerekliliğini ortaya çıkmaktadır,

- İşletmelerin kendi çalışanlarının sosyal sermayelerini artırmalarına yönelik olanak sağlaması gerekliliğini ortaya koyarak, çalışanlar ve işe başvuranlar açısından tercih edilebilirlikte öne plana çıkmasını sağlamalıdır.

İşletmelerin kişisel satış yapan personeli için yapılabilecek öneriler ise;

- Hem iş hem de özel yaşantıda önemli bir yere ve etkiye sahip olan sosyal sermaye farkındalığına erişmek gerekmektedir,

- Sahip olunan sosyal sermayenin sürekli bir artış içinde olması sağlanmalıdır. Bunun için de bulunulan çevre ile sürekli bir etkileşim halinde olunması önem arz etmektedir.

Sonuç olarak kişisel satış sürecinde hem örgütsel anlamda hem de kişisel anlamda başarıyı elde etmek için gerekli olan sosyal sermaye düzeyinin ön plana alınarak gerekli önemin verilmesi gereklidir. Sosyal sermaye düzeyinin artırılmasına yönelik yatırımın yapılması, çalışanların bu yönde motive edilmesi, örgüt içinde sosyal sermayeyi geliştirmeye yönelik teşvik edici ortamın oluşturulması sayesinde müşteri ilişkilerinde başarı elde edilerek rekabette öne geçilmesi sağlanabilecektir. Bu sayede gelişen sosyal sermaye düzeyi ile bilgiye erişim ve paylaşımda öne geçme imkânı doğacak ve günümüz bilgi çağında küresel kişilerin ve işletmelerin sosyal sermaye oluşumu sağlanarak başarı elde edilecektir. Gelecekte işe alımlarda sosyal bağlantıları fazla olan kişilerin tercihe edileceği günlerin çok yakın olduğu görülmektedir. İş ve işçi bulma kurumları head hunter (kafa avcısı) diye tabir edilen doğru pozisyona doğru kişiyi arayıp bulan ve nokta atışı yapan firmaların günümüzde facebook, linkedin, twitter, youtube, instagram gibi sosyal medya uygulamalarından faydalanmak sureti ile kişisinin bağlantılı olduğu sosyal çevrenin büyüklüğü, niteliği gibi unsurları ön plan çıkaracağı öngörülmektedir. Zira sosyal çevrenin yani sosyal sermayenin gücü oranında kişinin içinde bulunduğu atmosferi etkileme kabiliyetinin değiştiği bu çalışmadan çıarılacak bir diğer sonuçtur. 


\section{KAYNAKÇA}

Akçay, S. (2005). Sosyal Sermaye ve Kalkınma, İktisadi Kalkınmada Sosyal. Kültürel ve Siyasal Faktörlerin Rolü, Ed: Muhsin Kar ve Sami Taban, Ekin Yayınevi, Ankara

Aktepe, C., Tolon, M. ve Baş, M. (2015). Müşteri İlişkileri Yönetimi, Detay Yayıncllık, Ankara

Arabacı, B. (2008). Müşteri Hizmetleri ve CRM, Kum Saati Yayınları, İstanbul

Aslan, S. (2012). "Demokrasi Bağlamında Sosyal Sermaye ve Sivil Toplum İlişkisi", Mustafa Kemal Üniversitesi Sosyal Bilimler Enstitüsü Dergisi, 9(20), 45-58.

Assael, H. (1990). Marketing: Principles and Strategy, The Dryen Press

Baker, W. (2000). Achieving Success Through Social Capital, John Wiley \& Son Inc., New York

Bakırtaş, H. (2013). Müşteri İlişkileri Yönetimi, AÖF Yayını No:1954

Büyüköztürk, Ş., Çakmak, E.K., Akgün, Ö.E., Karadeniz, Ş., Demirel, F. (2017). Bilimsel AraştırmaYöntemleri, PEGEM Akademi, Ankara

Çabuk, S. (1999). Satış Yönetimi, Baki Kitabevi, Adana.

Çakar, M. (2008). Ankara'ya yerleşen Kosova-Prizren Göçmenlerinin İçsel ve Dışsal Sosyal Sermaye Kullanımları: Örnek Olay Çalışması, Yayımlanmamış Yüksek Lisans Tezi, Hacettepe Üniversitesi, Ankara.

Çelik, A. ve Şimşek, M. Ş. (2012). İşletme Bilimine Giriş, Konya

Demirören, P. (2009). Türk Bankacıllk Sektöründe Müşteri İlişkileri Yönetimi Uygulamalarının Müşteri Tatmini ve Müşteri Sadakatine Etkileri, Yayınlanmamış Yüksek Lisans Tezi, Niğde Üniversitesi, Niğde

Ekinci, A. (2010). Okullarda Sosyal Sermaye, Nobel Yayın Dağıtım, Ankara.

Eser, Z., Korkmaz, S. ve Öztürk, S.A. (2011). Pazarlama, 2. Baskı, Siyasal Kitapevi, Ankara

Gerşil, G. ve Aracı, M. (2011). “Sosyal Sermayenin Güven Unsurunun İş Görenlerin Performansı Üzerine Etkileri", Çalışma ve Toplum Dergisi, 1(28), 39-74.

Global Lubricants Market (2018) Lubricants Market, Global Lubricants Market Web: https://www.mordorintelligence.com/industry-reports/lubricants-marketmarket?gclid=EAIaIQobChMI5teB3cj 4AIVxI2yCh31SwX9EAAYAyAAEgKWg D BwE, (Erişim tarihi: 13 Mart 2019)

Gürcü, P. İ. (2007). Satış Temsilcilerinin Performans Değerlendirmesinde Gizli Müşteri Araştırmalarının Kullanımı: XYZ şirketinde Bir Uygulama, Yayımlanmamış Yüksek Lisans Tezi, Yıldız Teknik Üniversitesi, İstanbul

İslamoğlu, A.H. ve Altunışık, R. (2009). Satış ve Satış Yönetimi, Sakarya Yayıncılık, Sakarya

Kar, M. ve Taban, S. (2005). İktisadi Kalkınmada Sosyal, Kültürel ve Siyasal Faktörlerin Rolü, Ekin Kitabevi, Bursa

Karagül, M. (2012). Sosyal Sermaye (Kapitalizmin Kör Noktası), Nobel Yayınevi, Ankara

Karagül, M. ve Masca, M. (2005). “Sosyal Sermaye Üzerine Bir İnceleme”, Ekonomik ve Sosyal Araştırmalar Dergisi, Bahar, 37-52

Kirman, A. (1998). Satışta Profesyonellik, Rota Yayın, İstanbul

Kotler, P. (2010). Pazarlama 3.0. (Çev. K. Dündar). Optimist, İstanbul

Kotler, P. and Armstrong G. (2008). Principles Of Marketing, Pearson, New Jersey

Neuman, W. L. (2012). Toplumsal Araştırma Yöntemleri: Nicel ve Nitel Yaklaşımlar I-II. Cilt, 5. Basım, Yayın Odası, İstanbul

Ören, K. (2007). “Sosyal Sermayede "Güven" Unsuru ve İşgücü Performansına Etkisi”, Kamu-İş Dergisi, 9(1), 71-90. 


$$
\text { Z. Erol - Y. Boylu 11/4 (2019) 3204-3220 }
$$

Özcan, B. (2011). Sosyal Sermaye ve Ekonomik Kalkınma, Yayınlanmamış Doktora Tezi, İstanbul Üniversitesi $\mathrm{SBE}$, İstanbul

Parıltı, N. (2003). Kişisel Satış Yönetimi ve Organizasyon, Gazi Kitapevi, Ankara

Petder (2019) Madeni Yağ Verileri, "Petder Aylık Petrol Bülteni", 1(7), .7, Web: http://www.petder.org.tr/Uploads/Document/7f767f39-7dba-4fbd-a8cf-5fd6b2f05c80.pdf?v636867069536172010 (Erişim tarihi: 13 Mart 2019)

Putnam, R.D. (2000). Bowling Alone: The Collapse and Revival of American Community, Simon and Schuster, New York.

Sabatini, F. (2006), "Social Capital, Public Spending and the Quality of Economic Development: The Case of Italy", Faculty of Economics And Business Administration, 1-35.

Spiro, R.L., Stanton, W.J. and Rich, G.A. (2003). Management of Sales Force, McGraw Hill

Taşkın, E. (2010). Satış Arkadaşınız, Kişisel Satış ve Satış Yönetimi, Türkmen Kitapevi, İstanbul

Tuncer, P. (2008). Satış Teknikleri, Adres Yayınları, Ankara

Tüylüoğlu, Ş. (2006). “Sosyal Sermaye İktisadi Performans ve Kalkınma: Bir Yazın Taraması”, Akdeniz İ.İ.B.F. Dergisi, 12, 14-60.

Tüysüz, N. (2011a). Sosyal Sermayenin Ekonomik Gelişme Açısından Önemi ve Sosyal Sermaye endeksinin Hesaplanması, Kalkınma Bakanlığı Bölgesel Gelişme ve Yapısal Uyum Genel Müdürlüğü, Ankara

Uslu, A. T. (2006). Kişisel Satış Teknikleri, Beta Yayınları, İstanbul

Yıldırım, A. ve Şimşek, H. (2008). Sosyal Bilimlerde Nitel Araştırma Yöntemleri, Seçkin Yayıncılık, 6.Baskı, Ankara. 